ISSN 2455-2550

DOI: http://dx.doi.org/10.20431/2455-2550.0202001

www.arcjournals.org

\title{
Nanoparticles Effects of Red Grape (Vitis vinifera) Seeds and Grape Seeds Powder on Obese Hyperlipidemic Rats
}

\author{
Mohamed S.M.E.Abdelbaky ${ }^{1}$, Hoda S. Ibrahim ${ }^{2}$, Mohamed L. Hassan ${ }^{3}$, \\ Zahraa E. Sayed ${ }^{4}$ \\ ${ }^{1,2}$ Professor of Nutrition at Nutrition and Food Science dept., \\ Faculty of Home Economics, Helwan Univesity. \\ ${ }^{3}$ Professor at Department of cellulose - National Center for Research \\ ${ }^{4} \mathrm{Ph} . \mathrm{D}$ Researcher at Nutrition and Food Science dept., \\ Faculty of Home Economics, Helwan Univesity.
}

\begin{abstract}
Nanotechnology is emerging as a rapidly growing field with its wide application in science and technology for manufacturing of new materials at nanoscale level. This study aims to examine the effect of the nanoparticles of cellulose from grape seeds on obese hyperlipidemic rats.
\end{abstract}

Methods: Cellulose of grape seed were isolated by $15 \% \mathrm{NaoH}$ at $160 \circ \mathrm{C}$ for two hours, according to (Wise et al., 1946).Cellulose Nanocrystals (CNC) were isolated from grapes bleached pulp by acid hydrolysis using 65\% sulphuric acid at $45^{\circ} \mathrm{C}$ for 45 minutes as previously described (Hassan et al., 2014). Thirty (30) male albino rats of Sprague Dawley strain divided into six groups. Group(1) fed on the basal diet (negative control), (2)fed on the hyperlipidemic diet (HD) (positive control), (3) fed on HD $+2 \%$ nanoparticles from grape seeds (NGS), (4) fed on $H D+4 \% N G S$, (5) fed on $H D+5 \%$ grape seeds powder (GSP), (6) fed on HD +10\% GSP.

Total Phenolic Compounds, Concentration Phenolic Compounds, (SEM) examination, food intake, body weight gain ratio, lipids profile (Total lipids TL, Triglycerides TG, Total cholesterol TC, LDL, HDL \& VLDL), liver functions (AST, \& ALT), Total protein, albiumine, kidney functions (urea, uric acid \& creatinine) were determined.

Results: The results observed that rats treatment with nanocellulose from grape seeds (NGS 2\% \& 4\%) had significantly decrease in body weight gain ratio (BWG\%) and food intake; when compared with the positive control rats. Moreover, rats treatment with nanocellulose from grape seeds (NGS $2 \%$ \& $4 \%$ ) had significantly decrease in lipids profile levels (TL, TG, TC, LDL \& VLDL), Liver function \& Kidney functions than rats fed on $H D+G S P$ when compared with the positive control rats

Conclusions: It can be concluded that nanoparticles isolated from red grape seed specially Cellulose Nanocrystals $(\mathrm{CNC})$ had a significant positive effects against obesity and Hyperlipidemic than the effects of Grape Seeds Powder. Hence, the study may be repeated on patients with hyperlipidemia for possible beneficial effect on humans.

Keywords: Nanocellulose, hyperlipidemia, lipids, grape seeds, obesity.

\section{INTRODUCTION}

Obesity occurs when a controlled or regulated system fails to maintain energy balance, resulting in excess body fat storage. The obese population is increasing at an alarming rate throughout the world. Obesity causes many health problems, both independently and in association with other diseases (Formiguera \& Canton, 2004). Animal models, in which obesity and type 2 diabetes are induced by feeding high caloric diet, are of increasing interest for developing new therapeutic strategies.

Hyperlipidemia is a group of metabolic disorders characterizedby hypertriglyceride and/or hypercholesterol in blood circulation. The long-term hyperlipidemia is an important contributor to develop the progression of micro and macro vascular complications including microangiopathy, cardiovascular, cerebrovascular and metabolic syndrome diseases. The prevalence of hyperlipidemiahas dramatically increased worldwide due to a modern lifestyle and an increase of consumption of a high-fat diet (Jacobson et al., 2007). Consumption of dietary plant foods and their 
ingredients could be a more effective strategy for management of hyperlipidemia. Currently, fruits and vegetables have been screened for lipid digestion and absorption inhibitory agents.

It has recently become clear that grape seed extract(GSE) has shown various pharmacological effects such as chemo protective (Nandakumar et al., 2008) and oxidative stress as well as being antiinflammatory (Terraet al., 2009), anti-bacterial (Mayer et al., 2008), anticancer(Kaur et al.,2006), and anti-diabetic activities(Pinent et al., 2004). Recent study indicates that GSEinhibits pancreatic $\alpha$ amylase, and intestinal $\alpha$-glucosidases related to delay postprandial hyperglycemia(Adisakwattana et al., 2010).

The leaves and fruit of the grape have been used medicinally since ancient Greece. Today, grape seed extract is used as a folk or traditional remedy for conditions related to the heart and blood vessels, such as atherosclerosis (hardening of the arteries), high blood pressure, high cholesterol, and poor circulation; complications related to diabetes, such as nerve and eye damage; vision problems, such as macular degeneration (which can cause blindness); swelling after an injury or surgery; cancer prevention; and wound healing (Clouatre and Kandaswami, 2005).

Grape fruit contains various nutrient elements, such as vitamins, minerals, carbohydrates, edible fibers and phytochemicals. Polyphenols are the most important phytochemicals in grape because they possess many biological activities and health-promoting benefits (Wada et al., 2007).The phenolic compounds mainly include anthocyanins, flavanols, flavonols, stilbenes (resveratrol) and phenolic acids(Novaka et al.,2008).

Flavonoids are widely distributed in grapes, especially in seeds and stems, and principally contain (+)catechins, $(-)$-epicatechin and procyanidin polymers. Anthocyanins are the main polyphenolics in red grapes, while flavan-3-ols are more abundant in white varieties (Chacona et al., 2009).

Nanotechnology is emerging as a rapidly growing field with its wide application in science and technology for manufacturing of new materials at nanoscale level (Albrecht et al., 2006). This technology gained a tremendous impetus due to its capability of reformulating metals into new nanosized particles, with dimension less than $100 \mathrm{~nm}$ in size. Due to nano-particle size, their physiochemical properties drastically changes leading to broad spectrum of new applications.

The reported evidences of beneficial health effects of phenolic compounds include inhibiting some degenerative diseases, such as cardiovascular diseases (Shanmuganayagam et al., 2007), and certain types of cancers (God et al., 2007), reducing plasma oxidation stress and slowing aging (Meyer et al., 1997).

The beneficial effects of grape seeds are due to their antioxidant activities, scavenging free radicals, and inhibiting lipid peroxidation (Ahn et al., 2002; Spranger et al., 2008). Furthermore, grape seeds possess cardio protective effects by alleviating inflammatory conditions and reducing oxidative stress (Sato et al., 2001).

A lot of research works have been performed all over the world on the use of cellulose fibers as a reinforcing material for the preparation of various types of composites. However, lack of good interfacial adhesion, low melting point, and water sensitivity make the use of cellulose-fiber reinforced composites less attractive. Pretreatments of the cellulose fibers can modify the fiber surface, such as chemical functionalization stop the moisture absorption process and increase the surface roughness(Kalia et al., 2009).

Recently studies shown that grape seed extract significantly reduces plasma cholesterol in rabbits fed a high cholesterol diet. This action reduces the risk of atherosclerosis and coronary heart disease (Yamakoshi et al., 1999). Many attempts to find the responsible mechanisms for anti-hyperlipidemic activities of GSE have been studied, particularly in the inhibition of lipase (Moreno et al., 2003), and cellular cholesterol uptake (Leifert \&Abeywardena, 2008). Although, a great deal of work has been carried out to investigate its mechanisms, we hypothesize that grape seed extract may play other roles for controlling postprandial hyperlipidemia by inhibition of lipid digestion and absorption.

Recently studies shown that GSE significantly reduces plasma cholesterol in rabbits fed a high cholesterol diet. This action reduces the risk of atherosclerosis and coronary heart disease (Yamakoshi et al., 1999). Many attempts to find the responsible mechanisms for anti-hyperlipidemic activities of GSE have been studied, particularly in the inhibition of lipase (Moreno et al., 2003), and cellular 
Nanoparticles Effects of Red Grape (Vitis vinifera) Seeds and Grape Seeds Powder on Obese Hyperlipidemic Rats

cholesterol uptake (Leifert et al., 2008). The aim of this present study was to evaluate the effect of nanocellulose on obese hyperlipidemic rats.

\section{Materials AND Methods}

\section{2-1.Animals}

Male albino rats ( $\mathrm{n}=30 \mathrm{rats})$ weighing $(60.00 \pm 5.00 \mathrm{~g})$ of Sprsgue Dawley strain were obtained from the Laboratory Animals Colony, Ministry of Health and Population, Helwan, Egypt.

\section{2-2. Materials}

\section{2-2-1.Chemicals}

Casein was obtained from Morgan Company of chemical and nutritional products, Cairo, Egypt.Vitamins mix, minerals mix,cellulose and choline were obtained from El-gomhoria Company (Co.) for pharmaceutical and chemicals, Cairo, Egypt.

\section{2-2-2.Kits}

Kits used to determine serum total lipid ,total cholesterol, triglycerides, HDL-c,LDL-c,VLDL-c, AST, ALT, total protein ,Albumin ,Urea ,Uric and Creatinine were being obtained from Gamma Trade Co. for pharmaceutical and chemicals, Dokki, Egypt.

\section{2-3.Preparation of Grape Seed Powder}

Grape seeds were collected from local market, grape seed sample were grinded by using (dry blander, Panasonic) and the powder formed was sieved until certain sizes were achieved.

\section{2-4. Determination of Total Phenolic and Flavonoids Compounds}

A sample from grape seeds powder were taken to determine Phenolic compounds and Flavonoids according to(Goupy et al., 1999; Mattila et al., 2000).

\section{2-5. Extraction of Cellulose from Grape Seed}

Grape seed were washed with water, and pulped using $15 \% \mathrm{NaoH}$ at $160 \circ \mathrm{C}$ for two hours. The produced pulp was further bleached using sodium chlorite/acetic acid mixture according to previously published method (Wise et al., 1946).

\section{2-5-1.Preparation of Nanocellulose}

Cellulose Nanocrystals (CNC) were isolated from grapes bleached pulp by acid hydrolysis using $65 \%$ sulphuric acid at $45^{\circ} \mathrm{C}$ for 45 minutes as previously described (Hassan et al., 2014). The hydrolyzed cellulose sample was washed five times by centrifugation $\left(10.000 \mathrm{rpm}, 10 \mathrm{~min}\right.$, and $\left.10{ }^{\circ} \mathrm{C}\right)$ to remove excess sulphuric acid .The suspension was then dialyzed against distilled water until a constant $\mathrm{PH}$ was achieved .The resultant cellulose nanocrystal suspension was stored at $4 \pm^{\circ} \mathrm{C}$ until further used.

\section{2-6. Scanning Electronic Microscopy (SEM) examination}

Transmission electron microscopy (TEM) of the prepared cellulose nanocrystals was carried out using a JEOL 1230 transmission electron microscope (Japan) with acceleration voltage $100 \mathrm{kV}$.

\section{2-7. Preparation of the basal dietand high fat diet}

Basal diet and high fat diet for rats was prepared according to AIN 93M(Reeves et al., 1993).

Hypercholesterolemic diet (high fat diet) : groups were fed a modified AIN-93G diet containing 5 $\mathrm{g} / 100 \mathrm{~g}$ lard, $1 \mathrm{~g} / 100 \mathrm{~g}$ cholesterol, and $0.25 \mathrm{~g} / 100 \mathrm{~g}$ cholate according to (G Xu et al., 2007).

\section{2-8. Experimental Animals and Design}

The present experiment was done in the animal house, Faculty of Home Economics, Helwan University, Cairo, Egypt. It was carried out on $\left(\mathrm{n}_{=} 30\right)$ male albino rats of Sprague Dawley strain $(60.00 \pm 5.00 \mathrm{~g}$ b.wt.). Animals were housed in a normal healthy condition and allowed water was available. High fat diet was provided for four (4) week before starting the experiment. After this period (four week) rats were divided into two main groups. Then the rats will be divided into six (6) groups. Each group containing 5 rats. Group (1): Fed on the basal diet (the negative control). Group 
(2): Fed on the hyperlipidemic diet without supplementation (the positive control).Group (3): Fed on the hyperlipidemic diet $+2 \%$ of nanoparticles from grape seeds. Group (4): Fed on the hyperlipidemic diet (HD) $+4 \%$ of nanoparticles from grape seeds (NGS). Group (5): Fed on the hyperlipidemic diet (HD) $+5 \%$ from grape seeds powder (GSP). Group (6): Fed on the hyperlipidemic diet (HD) $+10 \%$ from grape seeds powder (GSP). At the end of the experimental period (four (4) weeks), rats will be fasted overnight before sacrifice and the blood will be collected and centrifuged for collection the serum.

\section{2-9. Biological Determination}

Biological determination were carried out by determination of feed intake (FI) which was calculated every day throughout the experimental period (4 weeks). Over all Body weight gain (BWG) and organs relative weight were determined according to (Chapman et al., 1959).

\section{2-10. Collection of Serum and Tissue Samples}

At the end of the experimental period (4 weeks), rats were sacrificed. Blood samples were immediately collected in clean and dry tubes from the portal vein and left to clot at room temperature. Blood samples were centrifuged at $3000 \mathrm{rpm}$ for 15 minutes to separate serum. Serum was carefully separated into dry clean tubes and allowed to be frozen at $-10^{\circ} \mathrm{c}$ until the determination of the tested parameters.

\section{2-11. Biochemical Analysis}

2-11-1. Determination of Triglycerides Concentration: Serum triglycerides was determined according to(Fossati \& Prancipel, 1982).

2-11.2.Determination of Total Cholesterol Concentration: Serum cholesterol was determined according to (Allain et al., 1974).

2-11-3. Determination of HDL-Cholesterol Concentration: Serum HDL-Cholesterol was determined according to (Burstein et al., 1970).

2-11-4. Determination of LDL-Cholesterol and VLDL -Cholesterol Concentration: Serum LDLCholesterol and VLDL-Cholesterol were determined according to(Friedewald et al., 1972).

2-11-5. Determination of Serum Alanine amino transferase (ALT): The enzyme alanine amino transeferase (ALT) This enzyme was determined in serum according toSherwin (1984).

2-11-6. Determination of Serum Aspartate Amino Transferase (AST): The enzyme aspartate amino transeferase (AST) was determined according to Young (1990).

2-11-7.Determination of Total Lipid: Determination of total lipid was according to Folch et al., 1957.

2-11-8.Determination of Serum Albumin Concentration: Serum albumin level was determined as described by Young (1990) using spectrophotometer at $630 \mathrm{~nm}$.

2-11-9.Determination of Total Protein Concentration: Protein concentrations were determined by the method of Lowry et al. (1951) using bovine serum albumin as the standard.

2-11-10.Determination of Urea, Uric acid and Creatinine Concentration: Urea, Uric Acid and Creatinine were determined according to (Young, 1995).

\section{2-12. Statistical Analysis of Data}

Results of biochemical analysis and biological evaluation of each group were Statisticalanalyzed(Mean, Standard deviation and one way ANOVA teat)using SAS package and compared with each other using suitable test [Least Significant difference (L.S.D.)and correlation coefficient] (Armitage \& Berry,1987).

\section{RESUlts AND DiscuSSION}

\section{3-1. Antioxidants of Red Grape Seeds Powder}

The DPPH radical is commonly used for the assessment of antioxidant potency in vitro and is foreign to biological systems (Zhou \& $\mathbf{Y u}, \mathbf{2 0 0 4})$. DPPH is a very stable organic free radical with deep violet colour, which gives absorption maxima within the $515-528 \mathrm{~nm}$ range. Upon receiving a proton from 

Hyperlipidemic Rats

any hydrogen donor, mainly from phenolics, it loses it chromophore and becomes yellow. By increasing the concentration of phenolic compounds or degree of hydroxylation of the phenolic compounds, their DPPH radical scavenging activity also increases, and can be defined as antioxidant activity (Sanchez, et al. 1999). Because these radicals are very sensitive to the presence of hydrogen donors, the whole system operates at a very low concentration; a large number of samples can be tested in a short time (Iqbal et al., 2006; Zhou \& Yu, 2004).

Table (1). DPPH (1,1-diphenyl-2-picrylhydrazyl) Radical Scavenging Activity of Antioxidants and Total Phenolic Compounds Contents of Red Grape Seeds Powder

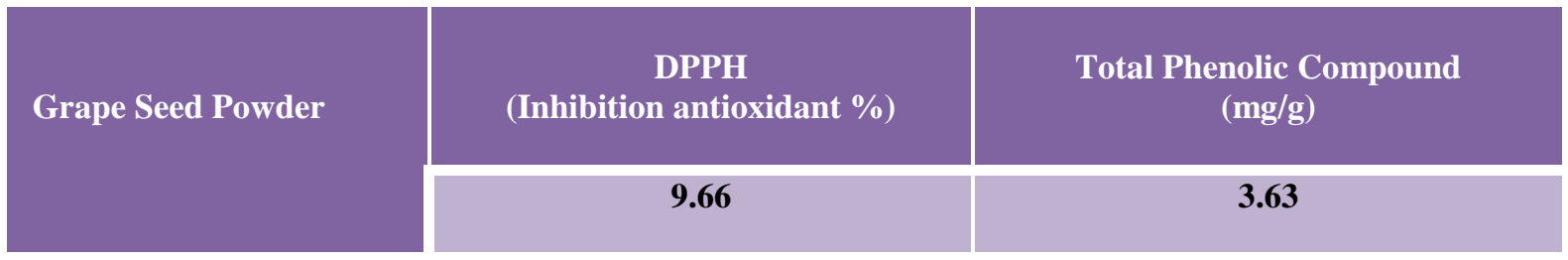

The proton radical scavenging action is known to be one of the various mechanisms for measuring antioxidant activity. Table(1) shows the inhibition antioxidant percent values of DPPH radical aboutthe activity of test compounds with stable free radicals and its effect is thought to be due to their hydrogen donating ability as (9.66\%) and Polyphenols content of methanol extract red grape seeds (3.63 mg /g ); These result were in agreement with (Junjie et al., 2009).

\section{3-1-1. High Performance Liquid Chromatography (HPLC)}

Table (2): The Concentration Phenolic Compounds ( $\mu \mathrm{g} / 100 \mathrm{~g})$ in Investigated Samples of Red Grape Seeds Powder (GSP) by HPLC:

\begin{tabular}{|l|}
\multicolumn{1}{|c}{ Phenolic Compounds } \\
\hline Gallic \\
\hline Pyrogallol \\
\hline 3-OH-Tyrosol \\
\hline 4-Amino-benzoic \\
\hline Protocatechuic \\
\hline Chlorogenic \\
\hline Catechol \\
\hline EpiCatechein \\
\hline Catechein \\
\hline Caffeine \\
\hline P-OH- benzoic \\
\hline Caffeic \\
\hline Vanillic \\
\hline Ferulic \\
\hline Iso- ferulic \\
\hline e-vanillic \\
\hline Reversetrol \\
\hline Oleuropin \\
\hline Ellagic \\
\hline Alpha - coumaric \\
\hline Benzoic \\
\hline 3.4.5-methoxy-cinnamic \\
\hline Coumarin \\
\hline Salycilic \\
\hline p-coumaric \\
\hline Cinnamic \\
\hline \\
\hline
\end{tabular}

\begin{tabular}{|c|}
\hline Test Results $(\mu \mathrm{g} / 100 \mathrm{~g})$ \\
\hline 26.77 \\
\hline 4290.66 \\
\hline 915.87 \\
\hline 327.74 \\
\hline 2901.00 \\
\hline 3598.44 \\
\hline 269.14 \\
\hline 135.26 \\
\hline 0.00 \\
\hline 95.87 \\
\hline 893.79 \\
\hline 244.85 \\
\hline 98.81 \\
\hline 133.28 \\
\hline 163.33 \\
\hline 9414.68 \\
\hline 50.29 \\
\hline 231.24 \\
\hline 201.02 \\
\hline 149.36 \\
\hline 3073.99 \\
\hline 88.16 \\
\hline 122.70 \\
\hline 336.05 \\
\hline 47.31 \\
\hline 105.03 \\
\hline \\
\hline
\end{tabular}

It is obvious that the total phenolic content measured by theFolin-Ciocalteu procedure does not give a full picture of the qualityor quantity of the phenolic constituents in the extracts as reported in 
literature (Katsube et al., 2004; Wu et al., 2004).PLC is the preferred technique for both separation and quantification of phenolic compounds (Naczk \& Shahidi, 2004). Various factors affectHPLC analysis of phenolics, including sample purification, mobile phase, column types and detectors (Stalikas, 2007). In general, purified phenolicsare applied to an HPLC instrument utilizing a reversed phase C18column (RP-C18), photo diode array detector (PDA) and polar acidified organic solvents(Ignat et al., 2011).

\section{3-2. Phenolic Compounds Content:-}

Polyphenolics compounds from grapes seeds attracted the attention of scientists to define their chemical composition and their properties for human health.The reported evidences of beneficial health effects of phenolic compounds include inhibiting some degenerative diseases, such as cardiovascular diseases.

The concentration of phenolic compounds of red grape seeds powder was recorded in Table (2). Data showed that HPLC analysis of phenolic compounds concentration (ug/100gm) in red grape seeds methanolic extract. It had the highest amounts of e-vanillic , Pyrogallol , Chlorogenic , Benzoic and Protocatechuic (9414.68, 4290.66, 3598.44, 3073.99 and 2901.00 ug/100g respectively). While the other phenolic compounds were shown Gallic, 3-OH-Tyrosol, 4-Amino-benzoic, Catechol, EpiCatechein, Caffeine, P-OH- benzoic, Caffeic, Vanillic, Ferulic, Iso- ferulic, Reversetrol, Oleuropin, Ellagic, Alpha - coumaric, 3.4.5- methoxy-cinnamic, Coumarin, Salycilic, p-coumaric and Cinnamic $(26.77,915.87,327.74,269.14,135.26,95.87,893.79,244.85,98.81,133.28,163.33$, $50.29,231.24,201.02,149.36,88.16,122.70,336.05,47.31$ and $105.0300 \mathrm{ug} / 100 \mathrm{~g}$ respectively); These result were in agreement with (Butkhup et al., 2010).

\begin{tabular}{|c|c|}
\hline Flavonoids & Test Results of Flavonoids $(\mu \mathrm{g} / 100 \mathrm{~g})$ \\
\hline Naringin & 36.75 \\
\hline Rutin & 12.15 \\
\hline Hisperdin & 126.94 \\
\hline Rosmarinic & 145.4 \\
\hline Quercetrin & 11.66 \\
\hline Quercetin & 17.2 \\
\hline Narengenin & 4.42 \\
\hline Kampferol & 13.52 \\
\hline Hispertin & 38.45 \\
\hline Apegenin & 90.79 \\
\hline 7-OH flavone & 7.06 \\
\hline
\end{tabular}

\section{3-3. Flavonoids Compounds Contents:-}

The concentration of flavonoids compounds in the samples of red grape seeds powder was recorded in Table (3).Data showed that HPLC analysis of flavonoids compounds concentration (ug/100gm) in red grape seeds methanolic extract. It had the highest amounts of Rosmarinic, Hisperdin and Apegenin $(145.4,126.94$ and $90.79 \mathrm{ug} / 100 \mathrm{~g}$, respectively). While the other flavonoids were shown Naringin, Rutin, Quercetrin , Quercetin, Narengenin, Kampfero, Hispertin and 7-OH flavones ( 36.75, 12.15, $11.66,17.2,4.42,13.52,38.45$ and $7.06 \mathrm{ug} / 100 \mathrm{~g}$,respectively) ); These result were in agreement with (Butkhup et al., 2010).

\section{3-4. Cellulose Nanocrystals Obtained From Red Grapes Seeds:-}

Figure (1) shows TEM images of cellulose nanocrystals isolated from grape seeds. The width of isolated nanocrystals was in the ranges from 4 to $7 \mathrm{~nm}$ while the length was in the range from 37 to 45 $\mathrm{nm}$ as recorded in Table (4), and Figure (2). Cellulose nanocrystals were oxidized by using TEMPOmediated chlorite oxidation; the reaction selectively converts the primary hydroxyl groups at the surfaces of cellulose nanocrystals to carboxylic acids. 
Nanoparticles Effects of Red Grape (Vitis vinifera) Seeds and Grape Seeds Powder on Obese Hyperlipidemic Rats
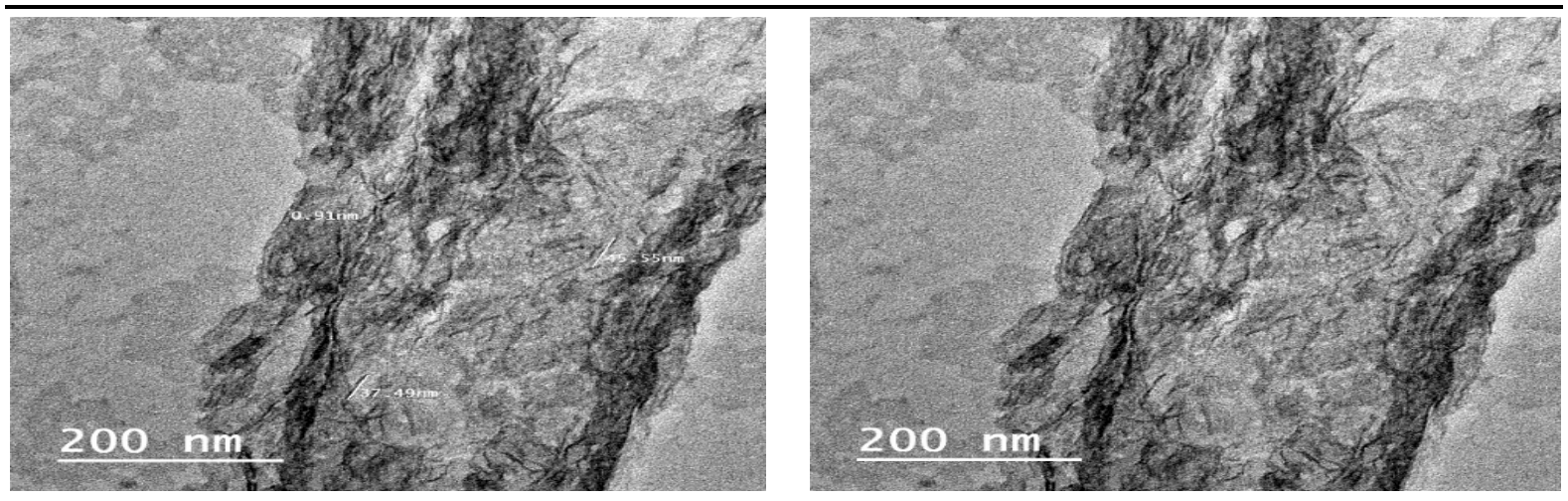

Figure (1). TEM images of cellulose nanocrystals obtained from red grapes seeds.

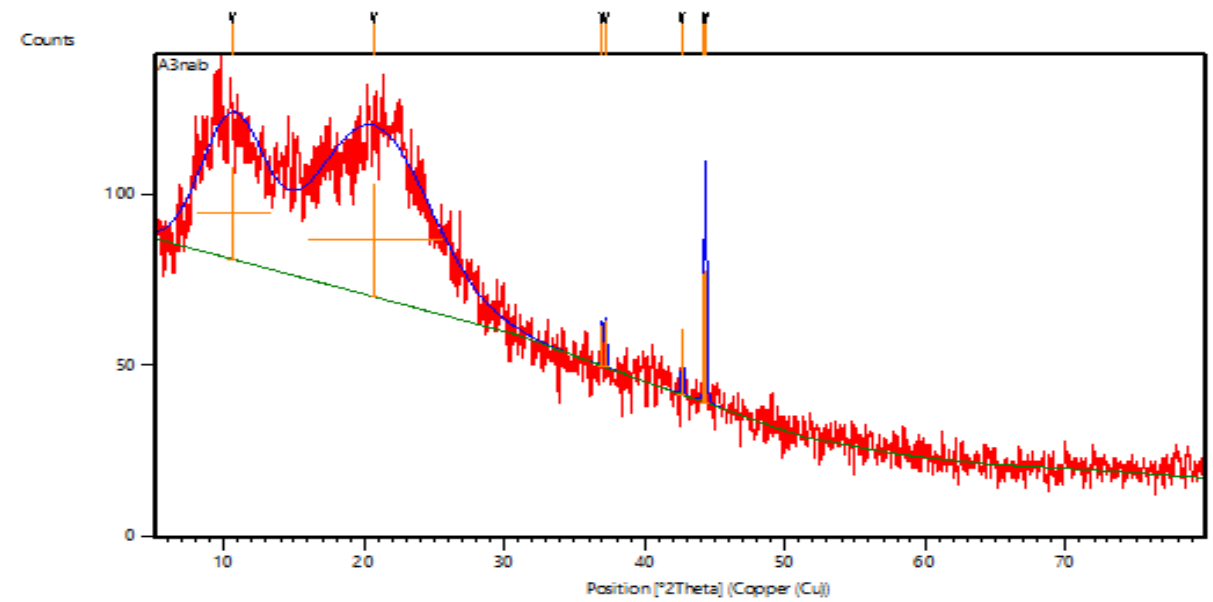

Figure (2). Crystallite Size Determination of Cellulose Nanocrystals Obtained from Red Grapes Seeds.

Table (4). Crystallite Size Determination of Cellulose Nanocrystals (CN) Obtained from Red Grape Seeds $(R G S)$

\begin{tabular}{|l|l|l|l|l|}
\hline Pos. ${ }^{\circ}{ }^{2}$ Th.] & Height $[\mathrm{cts}]$ & FWHMLeft $\left[{ }^{\circ}\right.$ 2Th.] & d-spacing $[\AA]$ & Rel.Int.[\%] \\
\hline 10.6137 & 27.09 & 5.2526 & 8.32847 & 69.40 \\
\hline 20.6502 & 33.40 & 9.5741 & 4.29775 & 85.56 \\
\hline 36.9943 & 12.28 & 0.0900 & 2.42800 & 31.47 \\
\hline 37.2072 & 13.60 & 0.0900 & 2.41459 & 34.84 \\
\hline 42.6411 & 19.57 & 0.0900 & 2.11862 & 50.13 \\
\hline 44.2787 & 37.67 & 0.1384 & 2.04399 & 96.51 \\
\hline 44.3506 & 39.03 & 0.0900 & 2.04084 & 100.00 \\
\hline
\end{tabular}

\section{3-5. Food Intake and Body Weight Gain Ratio}

\begin{tabular}{|c|c|c|}
\hline \multicolumn{3}{|c|}{$\begin{array}{l}\text { Table (5):Effect of Nanoparticles of Grape Seeds (NGS) and Grape Seeds Powder (GSP) on Food } \\
\text { Intake (FI) and Body Weight Gain ratio (BWG \%) in Obese Hyperlipidemic Rats (mean } \pm \text { SD). }\end{array}$} \\
\hline \multirow[t]{2}{*}{$\begin{array}{l}\text { Parameters } \\
\text { Groups }\end{array}$} & $\begin{array}{l}\text { Food Intake } \\
\text { (FI) }\end{array}$ & Body Weight Gain (BWG\%) \\
\hline & Mean \pm SD & Mean \pm SD \\
\hline G1:Control negative (C-) & $9.90^{f} \pm 0.00$ & $34.69^{b} \pm 3.01$ \\
\hline G2:Control positive $(\mathrm{C}+)$ & $16.00^{\mathrm{a}} \pm 0.00$ & $13.73^{\mathrm{d}} \pm 1.91$ \\
\hline G:3N.G.S $2 \%$ & $14.00^{\mathrm{c}} \pm 0.00$ & $-25.69^{c} \pm 2.20$ \\
\hline G4:N.G.S 4\% & $12.00^{\mathrm{d}} \pm 0.00$ & $-41.67^{\mathrm{a}} \pm 9.32$ \\
\hline G5:G.S.P. 5\% & $15.00^{\mathrm{b}} \pm 0.00$ & $-23.81^{\mathrm{c}} \pm 1.26$ \\
\hline G6:G.S.P. $10 \%$ & $10.80^{\mathrm{e}} \pm 0.00$ & $-21.58^{\mathrm{c}} \pm 1.92$ \\
\hline F. Value & $3.224 \mathrm{E}+32$ & 21.46 \\
\hline Sig. & 0.000 & 0.000 \\
\hline
\end{tabular}


The effect of grape seeds powder and it's nanoparticles on food intake and body weight gain ratio in experimental rats was recorded (Table 5). Results showed significant increase of food intake in rats suffering from hyperlipidemia (positive control group), with a mean value of $16.00^{\mathrm{a}} \pm 0.00 \mathrm{~g}$ compared with the negative control group with a mean value of $9.90^{\mathrm{f}} \pm 0.00 \mathrm{~g}$.

Results revealed that, rats fed on experimental diet containing $10 \%$ grape seeds powder had reduced food intake significantly with a mean value of $10.80^{\mathrm{c}} \pm 0.00 \mathrm{~g} /$ day compared to the positive control group. In addition rats fed on experimental diet containing $2 \%, 4 \%$ nanoparticles of grape seeds, and $5 \%$ grape seeds powder had reduced food intake significantly with a mean values of $14.00^{\mathrm{c}} \pm 0.00 \mathrm{~g}$, $12.00^{\mathrm{d}} \pm 0.00 \mathrm{~g}$ and $15.00^{\mathrm{b}} \pm 0.00 \mathrm{~g} /$ day, respectively, compared to the positive control .

Regarding body weight gain (BWG), it was significantly lowered $(\mathrm{P} \leq 0.05)$ for the positive control group when compared with the negative control group $\left(13.73^{\mathrm{d}} \pm 1.91 \mathrm{~g}\right.$, and $34.69^{\mathrm{b}} \pm 3.01 \mathrm{~g}$, respectively).However body weight gain (BWG) for rats group 3,4,5 and 6 showed significant decrease in BWG with mean values of $-25.69^{\mathrm{c}} \pm 2.20 \mathrm{~g},-41.67^{\mathrm{a}} \pm 9.32 \mathrm{~g},-23.81^{\mathrm{c}} \pm 1.26 \mathrm{~g}$ and $-21.58^{\mathrm{c}}$ $\pm 1.92 \mathrm{~g}$, respectively when compared with the positive control rats $13.73^{\mathrm{d}} \pm 1.91 \mathrm{~g}$. The results are agreement with $\boldsymbol{G U I} \mathbf{Y} \boldsymbol{u}$, et al., (2014) who studied hypolipidemic Effects of Different Particle Sizes of Cellulose from Sweet Potato Residue in Ovariectomized Hyperlipidemia Rats. Fortymature female Wistar rats were randomly divided into five groups. One group was sham-ovariectomized (OVX) as shamoperation group. The other four groups were double ovariectomized and one week later assigned as blank group, ordinarycellulose group, ultrafine cellulose group and nanocellulose group. Results reported that as the cellulose particle size decreased, the body weight gain and food intake of cellulose-fed OVX rats decreased.all three cellulose particles had a strong adsorption capacity towards fats, cholesterol and sodiumcholate and smaller particles size resulted in an increase in the adsorption capacity of fats and sodium cholate. Plasma totalcholesterol (TC), triglyceride (TG), and low density lipoprotein-cholesterol (LDL-C), arteriosclerosis index (AI) and livertotal fat and TG and of OVX rats exhibited a decrease. There were positive correlations between decreasing trends of plasmaTC, TG and LDL-C in OVX rats and cellulose particle size. It concluded that the adsorption capacity of cellulose towards fatand bile salts can be increased by reducing its particle size, consequently improving the hypolipidemic effect in OVX rats.

Various studies have shown that the intake of Polyphenols derived from many components of the human diet, prevents bodyweight gain and fat accumulation (Pinentet al., 2006; Meydani \& Hasan,2010;Rains et al.,2011). However, in most of the experiments performed with animals, thebody weight-related effects of polyphenols have been observedafter the administration of these compounds for a long timeand/or at high doses (Ohyama et al.,2011) In this study, we showed that theadministration of GSPand NGS at low doses, comparable to the average human consumption ofprocyanidins 32,33 when expressed as metabolic dose, significantlyreduces the body weight gain of rats fedeither an STD or an HFD.

\section{3-6. Organs(Liver,Kidney,Heart, and Spleen) toBody Weight (\%):-}

The bioactive effect of grape seeds powder and it's nanoparticles on liver, kidney, spleen and heart to body weight ratio in the experimental rats were recorded (Table 6). Results indicated insignificant difference between all groups on liver/ body weight\%. However, rats (positive control) had markedly decreased liver /body weight $\%$ with a mean value $2.70^{\mathrm{bc}} \pm 0.34 \%$ compared with rats fed

\begin{tabular}{|l|c|c|c|c|}
\hline $\begin{array}{c}\text { Table (6): Effect of Nanoparticles of Grape Seeds (NGS) and Grape Seeds Powder (GSP) on Organs } \\
\text { /Weight in Obese Hyperlipidemic Rats (mean } \pm \text { SD). }\end{array}$ \\
\hline \multirow{2}{*}{ Groups } & $\begin{array}{c}\text { Liver/ Weight } \\
\%\end{array}$ & $\begin{array}{c}\text { Kidney/ } \\
\text { Weight\% }\end{array}$ & $\begin{array}{c}\text { Heart / Weight } \\
\%\end{array}$ & $\begin{array}{c}\text { Spleen / Weight } \\
\%\end{array}$ \\
\cline { 2 - 5 } & Mean \pm SD & Mean \pm SD & Mean \pm SD & Mean \pm SD \\
\hline G1:Control negative (C-) & $3.33^{\mathrm{ab}} \pm 0.69$ & $0.85^{\mathrm{ab}} \pm 0.16$ & $0.36^{\mathrm{ab}} \pm 0.02$ & $0.34^{\mathrm{a}} \pm 0.13$ \\
\hline G2:Control positive (C+) & $2.70^{\mathrm{bc}} \pm 0.34$ & $0.69^{\mathrm{b}} \pm 0.11$ & $0.25^{\mathrm{cd}} \pm 0.03$ & $0.22^{\mathrm{b}} \pm 0.35$ \\
\hline G3:N.G.S 2\% & $2.17^{\mathrm{c}} \pm 0.20$ & $0.76^{\mathrm{b}} \pm 0.02$ & $0.31^{\mathrm{b}} \pm 0.01$ & $0.08^{\mathrm{c}} \pm 0.006$ \\
\hline G4:N.G.S 4\% & $3.77^{\mathrm{a}} \pm 0.87$ & $1.03^{\mathrm{a}} \pm 0.19$ & $0.38^{\mathrm{a}} \pm 0.052$ & $0.28^{\mathrm{ab}} \pm 0.02$ \\
\hline G5:G.S.P. 5\% & $2.55^{\mathrm{bc}} \pm 0.21$ & $0.78^{\mathrm{b}} \pm 0.78$ & $0.25^{\mathrm{d}} \pm 0.05$ & $0.24^{\mathrm{b}} \pm 0.02$ \\
\hline G6:G.S.P. 10\% & $2.70^{\mathrm{bc}} \pm 0.05$ & $0.87^{\mathrm{ab}} \pm 0.04$ & $0.30^{\mathrm{bc}} \pm 0.02$ & $0.25^{\mathrm{b}} \pm 0.01$ \\
\hline F. Value & 5.49 & 3.85 & 8.065 & 9.419 \\
\hline Sig. & 0.003 & 0.015 & 0.000 & 0.000 \\
\hline Values are expressed as mean \pm SD .Significance at the P $\leq 0.05$ level. \\
\hline
\end{tabular}


on basal diet (negative control group) with a mean value of $3.33^{\mathrm{ab}} \pm 0.69 \%$. However, rats fed on experimental diet containing $4 \%$ nanoparticles of grape seeds showed significant increase in liver / body weight $\%$ with a mean value of $3.77^{\mathbf{a}} \pm 0.87 \%$ compared with the positive control rats $\left(2.70^{\mathbf{b c}}\right.$ $\pm 0.34 \%$ ).Concerning kidney/ weight $\%$, it could be revealed that, non-significant difference for kidney / body weight $\%$ in all groups. Moreover, positive control group had insignificant decrease with a mean value $\left(0.69^{\mathrm{b}} \pm 0.11 \%\right)$ when compared with the negative control group with a mean value $\left(0.85^{\text {ab }}\right.$ $\pm 0.16 \%)$.

\begin{tabular}{|c|c|c|c|}
\hline \multirow[t]{2}{*}{ Parameters } & $\begin{array}{l}\text { Total lipids } \\
\text { (mg/dl) }\end{array}$ & $\begin{array}{c}\text { Total Cholesterol } \\
(\mathrm{mg} / \mathrm{dl})\end{array}$ & $\begin{array}{l}\text { Triglycerides } \\
\text { (mg/dl) }\end{array}$ \\
\hline & Mean \pm SD & Mean \pm SD & Mean \pm SD \\
\hline G1:Control negative (C-) & $257.07^{c} \pm 6.74$ & $64.99^{e} \pm 2.90$ & $87.2^{\mathrm{d}} \pm 4.02$ \\
\hline G2:Control positive $(\mathrm{C}+)$ & $661.72^{\mathrm{a}} \pm 6.85$ & $178.38^{\mathrm{a}} \pm 5.69$ & $345.32^{\mathrm{a}} \pm 4.21$ \\
\hline G3:N.G.S 2\% & $250.67^{\mathrm{c}} \pm 5.11$ & $74.80^{d} \pm 3.23$ & $120.65^{b} \pm 3.63$ \\
\hline G4:N.G.S 4\% & $199.34^{\mathrm{d}} \pm 2.62$ & $94.87^{b} \pm 6.31$ & $85.97^{d} \pm 6.08$ \\
\hline G5:G.S.P. 5\% & $291.52^{b} \pm 9.64$ & $86.07^{\mathbf{c}} \pm 2.43$ & $116.85^{b} \pm 5.02$ \\
\hline G6:G.S.P. $10 \%$ & $259.86^{\mathrm{C}} \pm 2.86$ & $84.42^{c} \pm 5.03$ & $103.07^{\mathbf{c}} \pm 5.23$ \\
\hline F. Value & 3057.6 & 330.18 & 1756.51 \\
\hline Sig. & 0.000 & 0.000 & 0.000 \\
\hline
\end{tabular}

Moreover, it could be showed that, insignificant difference between all groups in heart / body weight\%. However, rats (positive control) had markedly decreased in heart / body weight\% but was not statistically significant with a mean value $0.25^{\mathrm{cd}} \pm 0.03 \%$ compared with rats fed on basal diet (negative control group) with a mean value of $0.36^{\mathrm{ab}} \pm 0.02 \%$. However, rats fed on experimental diet containing $4 \%$ NGS had significant increase in heart / body weight \%t with a mean value of $\left(0.38^{\mathrm{a}}\right.$ $\pm 0.052 \%)$ compared with the positive control rats $\left(0.25^{\text {cd }} \pm 0.03 \%\right)$. In addition, it showed that rats (positive control) had significantdecreased spleen/ body weight $\%$ with a mean value $\left(0.22^{\mathrm{b}} \pm 0.35 \%\right)$ compared with rats fed on basal diet (negative control group) with a mean value of $\left(0.34^{\mathrm{a}} \pm 0.13 \%\right)$. However, rats fed on experimental diet containing $2 \%$ NGS had significant decrease in spleen/ body weight $\%$ with a mean value of $0.08^{\mathrm{c}} \pm 0.006 \%$ compared with the positive control rats $\left(0.22^{\mathrm{b}} \pm 0.35 \%\right)$.

\section{3-7. Blood Lipids Profile}

The bioactive effect of grape seeds powder and it's nanoparticles on total lipids, total cholesterol and triglycerides in experimental rats were recorded (Table 7) and figure (3).It could be observed that, all groups fed on basal diet (control negative group) and rats fed on hypercholesterolemic diet with nanocellulose from grape seeds (NGS 2\% \& 4\%) or grape seeds powder (GSP 5\% \& 10\%) had significant decreased in total lipids when compared with rats fed on hypercholesterolemic diet without supplementation (control positive group).Also, The lowest value was recorded with group administrated by nanocellulose from grape seeds (NGS 4\%) which it had highly significant decreased in total lipids with $199.34^{\mathrm{d}} \pm 2.62$ compared with negative and positive control groups with a mean value of $257.07^{\mathrm{c}} \pm 6.74$ and $661.72^{\mathrm{a}} \pm 6.85$ respectively . Moreover, the same results indicated that significant decreased in total cholesterol and triglycerideswere recorded for rats fed on basal diet (control negative group) and rats fed on hypercholesterolemic diet supplemented with nanocellulose from grape seeds (NGS 2\% \& 4\%) or grape seeds powder (GSP 5\% \& 10\%)when compared with rats fed on hypercholesterolemic diet without supplementation (control positive group). Also, The lowest value in total cholesterol was recorded with group administrated with nanocellulose from grape seeds (NGS $2 \%$ ) $74.80^{\mathrm{d}} \pm 3.23$ compared with negative and positive control groups with a mean value of $64.99^{\mathrm{e}} \pm 2.90$ and $178.38^{\mathrm{a}} \pm 5.69$ respectively. In addition, The lowest value in triglycerides was recorded with group administrated with nanocellulose from grape seeds (NGS 4\%) 85.97 \pm 6.08 compared with negative and positive control groups with a mean value of $87.2^{\mathrm{d}} \pm 4.02$ and $345.32^{\mathrm{a}} \pm 4.21$ respectively. 
Table (8). Effect of Nanoparticles of Grape Seeds (NGS) and its powder (GSP) on Serum High Density Lipoprotein (HDL), Serum Low Density Lipoprotein (LDL) and Very Low Density Lipoprotein (VLDL) in Obese Hyperlipidemic Rats (mean $\pm S D$ ).

\begin{tabular}{|l|c|c|c|}
\hline \multicolumn{1}{c|}{$\begin{array}{c}\text { Parameters } \\
\text { Groups }\end{array}$} & $\begin{array}{c}\text { HDL } \\
(\mathbf{m g} / \mathbf{d l})\end{array}$ & $\begin{array}{c}\text { LDL } \\
(\mathbf{m g} / \mathbf{d l})\end{array}$ & $\begin{array}{c}\text { VLDL } \\
(\mathbf{m g} / \mathbf{d l})\end{array}$ \\
\hline G1:Control negative (C-) & Mean \pm SD & Mean \pm SD & Mean \pm SD \\
\hline G2:Control positive (C+) & $29.70^{\mathbf{b}} \pm 1.80$ & $17.85^{\mathbf{c}} \pm 1.32$ & $17.44^{\mathbf{d}} \pm 0.80$ \\
\hline G3:N.G.S 2\% & $41.70^{\mathbf{a}} \pm 2.04$ & $67.62^{\mathbf{a}} \pm 4.65$ & $69.06^{\mathbf{a}} \pm 0.84$ \\
\hline G4:N.G.S 4\% & $30.90^{\mathbf{b}} \pm 3.00$ & $19.77^{\mathbf{c}} \pm 1.66$ & $24.13^{\mathbf{b}} \pm 0.72$ \\
\hline \hline G5:G.S.P. 5\% & $47.10^{\mathbf{a}} \pm 0.75$ & $30.58^{\mathbf{b}} \pm 4.18$ & $17.19^{\mathbf{d}} \pm 1.21$ \\
\hline G6:G.S.P. 10\% & $48.00^{\mathbf{a}} \pm 2.19$ & $14.70^{\mathbf{c}} \pm 1.74$ & $23.37^{\mathbf{b}} \pm 1.00$ \\
\hline F. Value & $33.60^{\mathbf{b}} \pm 8.87$ & $30.21^{\mathbf{b}} \pm 4.14$ & $20.61^{\mathbf{c}} \pm 1.04$ \\
\hline Sig. & 15.66 & 142.70 & 1756.51 \\
\hline Values are expressed as mean \pm SD .Significance at the $\mathbf{P} \leq \mathbf{0 . 0 5}$ level. & 0.000 \\
\hline
\end{tabular}

Data in table (8) were showed the effect of grape seeds powder (GSP) and nanocellulose from grape seeds (NGS) on (HDL, LDL and VLDL) lipoproteins in obese hypercholesterolemic rats .It could be showed that serum high density lipoprotein (HDL) was significantly increased in rats suffering from hyperlipidemia (positive control group) with a mean value of $\left(41.70^{\mathrm{a}} \pm 2.04 \mathrm{mg} / \mathrm{dl}\right)$ compared with the negative control group with a mean value of $\left(29.70^{\mathrm{b}} \pm 1.80 \mathrm{mg} / \mathrm{dl}\right)$. However, groups administrated grape seeds powder (GSP 5\%) or nanocellulose from grape seeds (NGS 4\%) had non-significant increase in serum high density lipoprotein (HDL) when compared to the positive control groups.

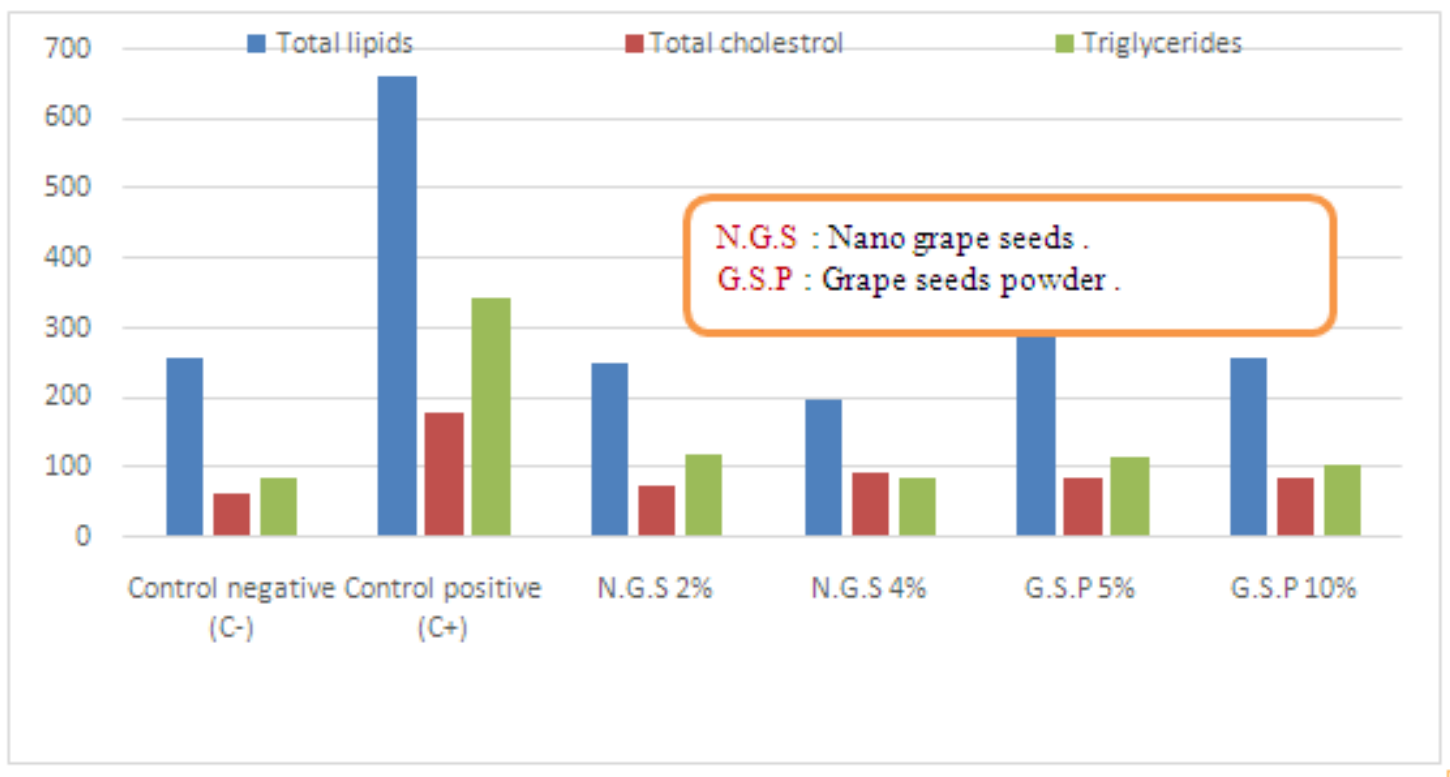

Figure (3). Effect of Nanoparticles of grape seeds and its powder on obese hyperlipidemic

In the same table, results showed that serum low density lipoprotein (LDL) and very low density lipoprotein (VLDL) were increased significantly in rats suffering from hyperlipidemia (positive control group) with a mean value of $\left(67.62^{\mathrm{a}} \pm 4.65 \mathrm{mg} / \mathrm{dl}\right)$ and $\left(69.06^{\mathrm{a}} \pm 0.84 \mathrm{mg} / \mathrm{dl}\right)$ respectively, compared with the negative control group with a mean value of $\left(17.85^{\mathrm{c}} \pm 1.32 \mathrm{mg} / \mathrm{dl}\right)$ and $\left(17.44^{\mathrm{d}}\right.$ $\pm 0.80 \mathrm{mg} / \mathrm{dl}$ ) respectively. While, allgroups fed on hypercholesterolemic diet supplemented with grape seeds powder (GSP 5\% \& 10\%) or nanocellulose from grape seeds (NGS $2 \%$ \& 4\%) had significant decrease in serum LDL and VLDL when compared to the positive control rats. The lowest value in serum vLDL was recorded by group (NGS 4\%). The results are agreement withGUI Yu, et al., (2014).Also, Grapes(Vitis vinfera L.) are considered the world's mostprevalent fruit crop. Their large amounts of phenolic compoundshave made them the focus of extensive studies (Broussaud et al., 1999; Caillet et al., 2006; Bozan et al., 2008). In grapeberries, the phenolic compounds reside mainly in the skins andseeds (Rodriguez et al., 2006; Poudel et al., 2008). Flavonolsare the most abundant 

Hyperlipidemic Rats

phenolic compounds in grape skins, while grape seeds are rich in monomeric phenolic compounds,such as (+)-catechins, (-)-epicatechin and (-)-epicatechin-3-0-gallate, and dimeric, trimeric and tetrameric procyanidins. Thesecompounds act as antimutagenic and antiviral agents (Kammerer et al., 2004; Rodriguez et al., 2006), and inhibit the oxidation ofhuman low-density lipoproteins LDL) in vitro (Teissedre et al., 1996).

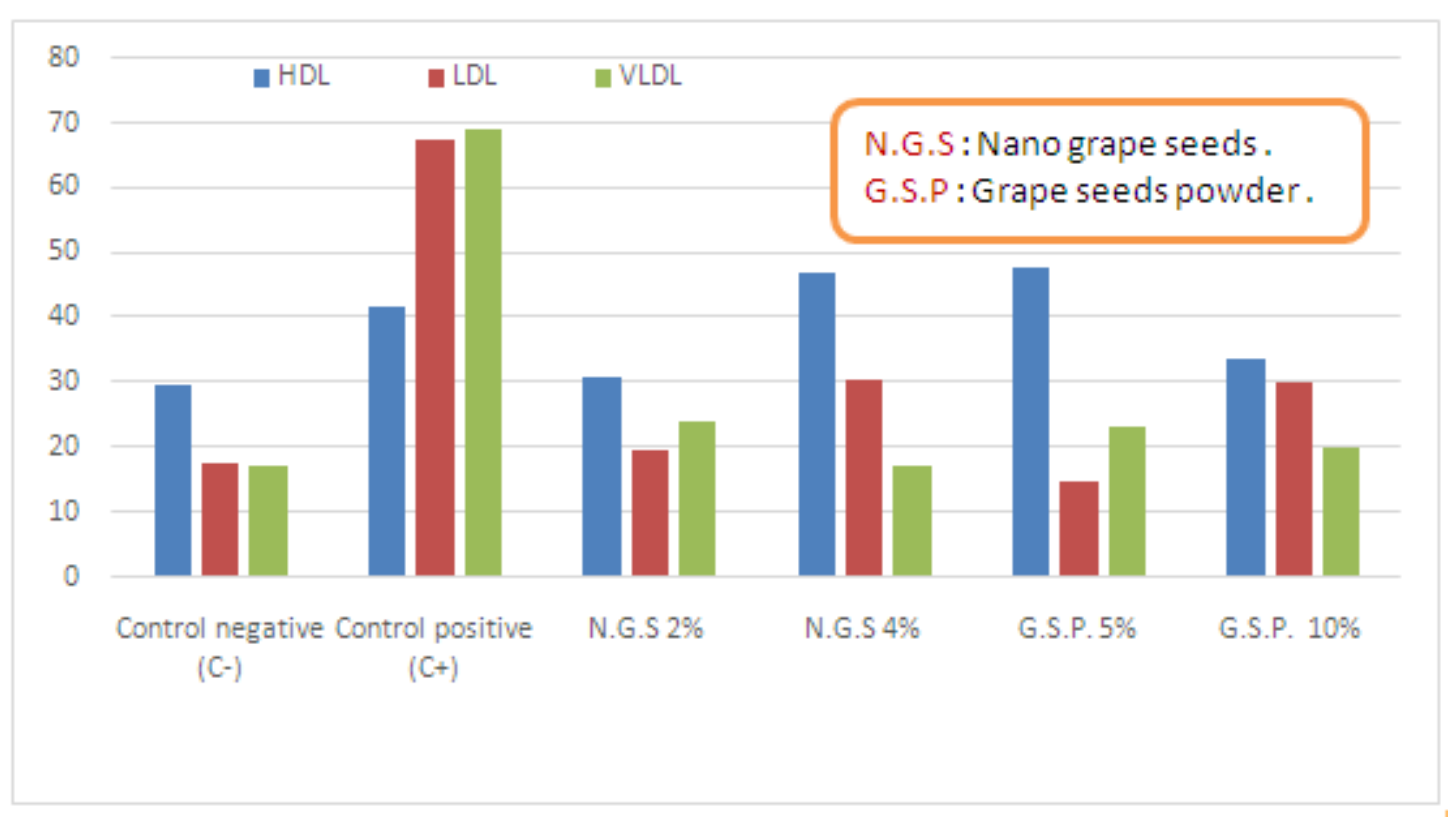

Figure (4). Effect of Nanoparticals of grape seeds and its powder on serum high density lipoprotein (HDL), serum low density lipoprotein $(L D L)$ and very low density lipoprotein on obese hyperlipidemic rats.

Moreover, the results are agreement with Liuand $\mathbf{L i}$ (2016) who reported that the effect of sweet potato residue cellulose on regulating blood glucose was more significant with the decrease of particle size. The content of serum insulin and hepatic glycogen increased significantly in group of nano sweet potatoresidue cellulose ( $\mathrm{CNC}$ group) $(\mathrm{p}<0.05)$. Nano sweet potato residue cellulose not only helped to decrease fasting blood glucose, glycosylated serum protein content, serum TC, TG and LDL-L content ( $\mathrm{p}<0.05$ ), but also led to a decrease in liver fat concentration, content of TC and TG, which indicated that nano sweet potato residue cellulose had favorable effects on improving pancreatic tissue morphology as well as reducing blood glucose.In addition, Zhong, etal., (2012)Compared the effects of nano-sized sugarcane fiber with cellulose and psyllium on hepatic cellular signaling in mice. Itsuggested that the modulation of gastrointestinal factors by dietary fibers may play a key role in both enhancing hepatic multiple cellular signaling and reducing lipid accumulation.

Table (9). Effect of Nanoparticles of grape seeds and its powder on serum total protein, albumin AST and ALT levels In obese hyperlipidemic rats (mean $\pm S D$ ).

\begin{tabular}{|l|c|c|c|c|}
\hline \multirow{2}{*}{$\begin{array}{c}\text { Proups } \\
\text { Parameters }\end{array}$} & $\begin{array}{c}\text { T. protein } \\
\mathrm{mg} / \mathrm{dl}\end{array}$ & $\begin{array}{c}\text { Albumin } \\
\mathrm{mg} / \mathrm{dl}\end{array}$ & $\begin{array}{c}\text { Serum AST } \\
(\mathrm{U} / \mathrm{L})\end{array}$ & $\begin{array}{c}\text { Serum ALT } \\
(\mathrm{U} / \mathrm{L})\end{array}$ \\
\cline { 2 - 5 } & Mean \pm SD & Mean \pm SD & Mean \pm SD & Mean \pm SD \\
\hline Control negative (C-) & $6.10^{\mathrm{ab}} \pm 1.04$ & $3.19^{\mathrm{ab}} \pm 0.00$ & $97.50^{\mathrm{d}} \pm 8.38$ & $43.52^{\mathrm{d}} \pm 3.23$ \\
\hline Control positive (C+) & $5.32^{\mathrm{bc}} \pm 0.27$ & $2 . .94^{\mathrm{b}} \pm 0.10$ & $153.62^{\mathrm{b}} \pm 10.60$ & $75.07^{\mathrm{ab}} \pm 15.89$ \\
\hline N.G.S 2\% & $4.61^{\mathrm{c}} \pm 0.24$ & $3.46^{\mathrm{a}} \pm 0.34$ & $129.89^{\mathbf{b c}} \pm 10.90$ & $66.82^{\mathrm{bc}} \pm 7.40$ \\
\hline N.G.S 4\% & $6.49^{\mathrm{a}} \pm 0.39$ & $3.21^{\mathrm{ab}} \pm 0.27$ & $214.38^{\mathrm{a}} \pm 33.57$ & $86.67^{\mathrm{a}} \pm 2.44$ \\
\hline G.S.P. 5\% & $6.62^{\mathrm{a}} \pm 0.25$ & $3.38^{\mathrm{ab}} \pm 0.49$ & $136.67^{\mathrm{bc}} \pm 8.07$ & $63.50^{\mathbf{b c}} \pm 6.30$ \\
\hline G.S.P. 10\% & $6.57^{\mathrm{a}} \pm 0.94$ & $3.32^{\mathrm{ab}} \pm 0.16$ & $116.05^{\mathrm{d}} \pm 14.08$ & $57.59^{\mathbf{c}} \pm 6.71$ \\
\hline F. Value & 6.79 & 1.70 & 23.24 & 12.27 \\
\hline Sig. & 0.001 & 0.185 & 0.000 & 0.000 \\
\hline Values are expressed as mean \pm SD .Significance at the P $\leq 0.05$ level. \\
\hline
\end{tabular}

\section{3-8. Liver Functions:}

Data in table (9) and figure (5 \& 6) showed the effect of grape seeds powder (GSP) and nanoparticles grape seeds (NGS) on serum concentrations of Total protein, Albumin, AST, and ALT in obese 
hypercholesterolemic rats.It could be observed that AST and ALT was significantly increased in rats suffering from hepatic damage (positive control group) with a mean value of $153.62^{\mathrm{b}} \pm 10.60 \& 75.07^{\mathrm{ab}}$ $\pm 15.89 \mathrm{U} / \mathrm{L}$ compared with the negative control group with a mean value of $97.50^{\mathrm{d}} \pm 8.38 \& 43.52^{\mathrm{d}}$ $\pm 3.23 \mathrm{U} / \mathrm{L}$ respectively.In addition, it revealed that rats were fed on grape seeds powder and nanoparticles of grape seeds in the diet showed reduction in the serum AST and ALT at different levels when compared with the positive control group except in group (4) rats fed on hypercholesterolemic diet supplemented with NGS 4\%. Also, the lowest reduction value of AST and ALT were found in group (6)when rats fed on hypercholesterolemic diet supplemented with GSP $10 \%$ $116.05^{\mathrm{d}} \pm 14.08 \& 57.59^{\mathrm{c}} \pm 6.71 \mathrm{U} / \mathrm{L}$ respectively .

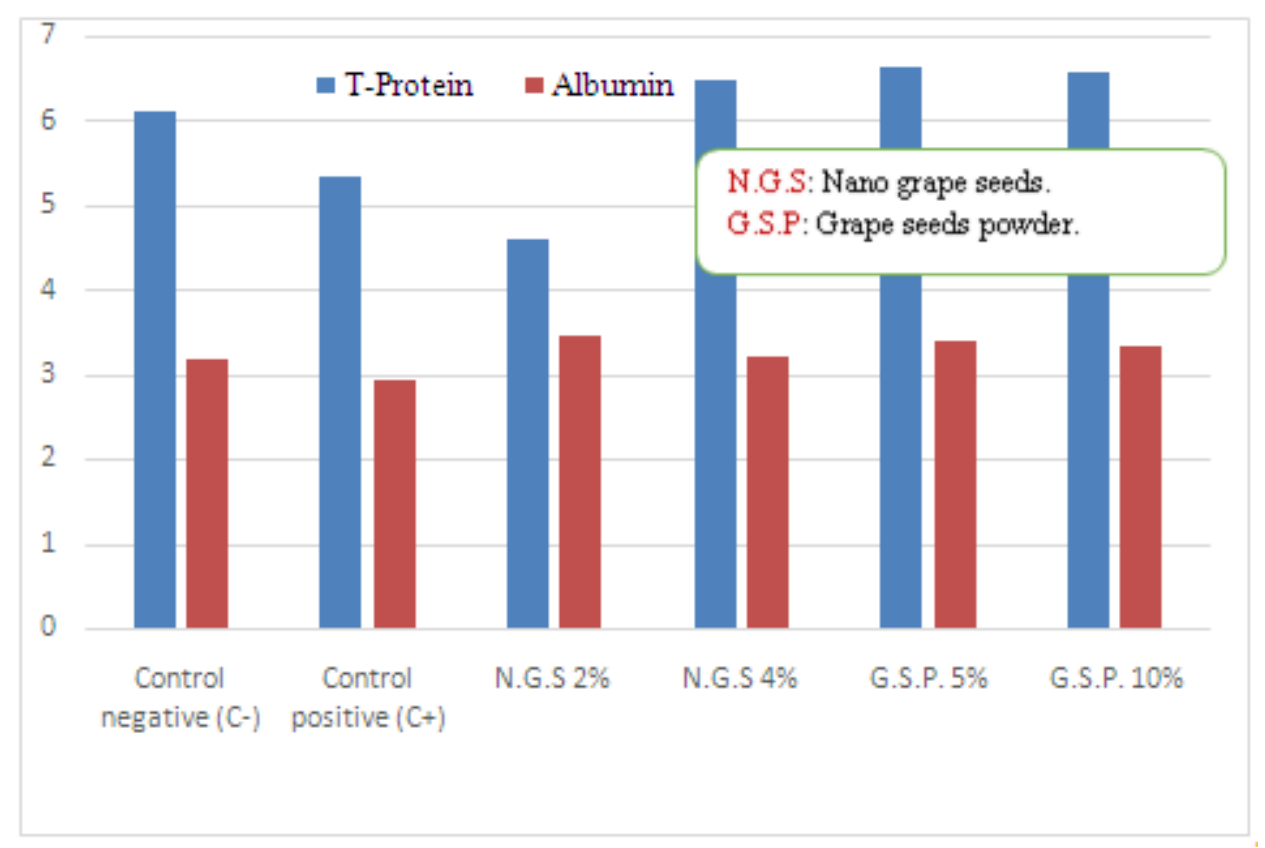

Figure (5). Effect of Nanoparticles of grape seeds and its powder on total protein and albumin levels in obese hyperlipidemic rats.

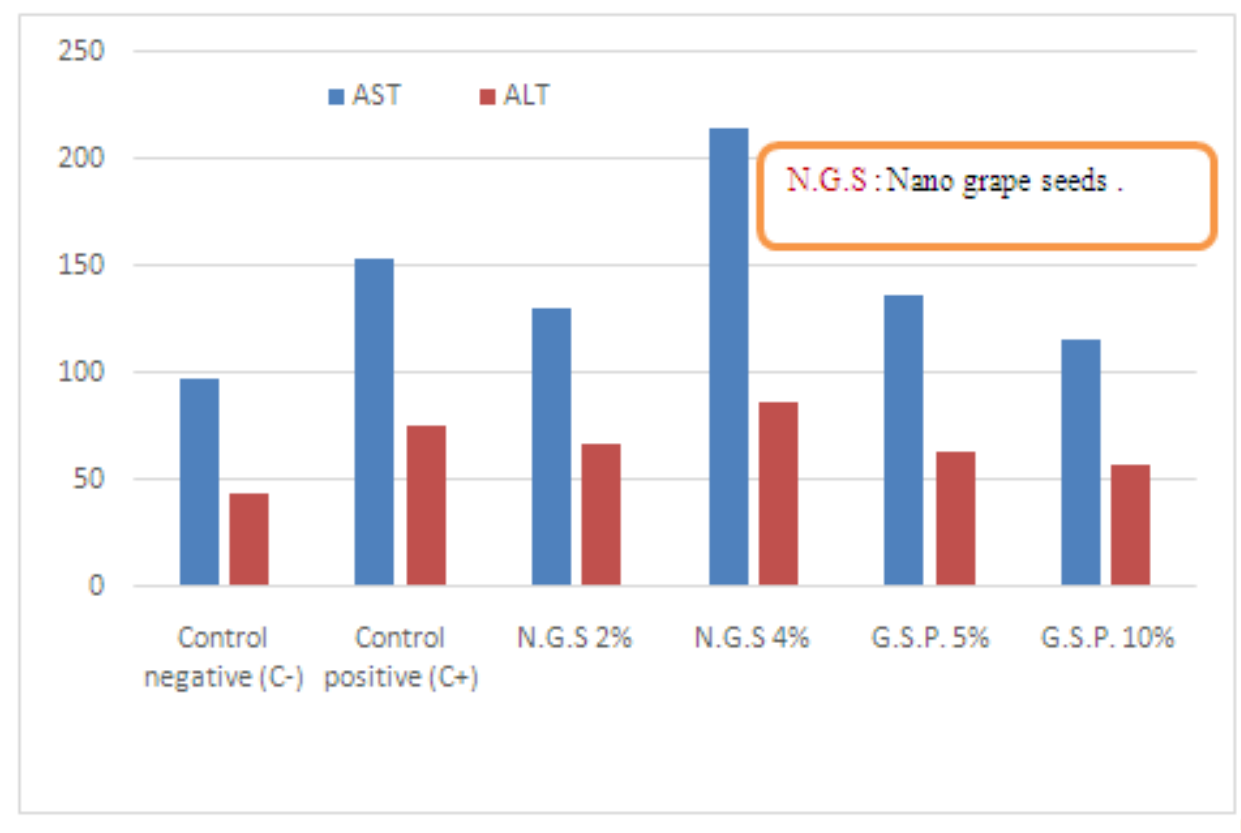

Figure (6). Effect of Nanoparticles of grape seeds and its powder on serum liver function (AST and ALT) in obese hyperlipidemic rats.

Moreover, from the same data, it could be observed that markedly decreased was recorded in total protein and albumin for rats fed on hypercholesterolemic diet without supplementation (positive control group ) with a mean value $5.32^{\mathrm{bc}} \pm 0.27 \& 2 . .94^{\mathrm{b}} \pm 0.10 \mathrm{mg} / \mathrm{dl}$ compared with the negative control group with a mean value $6.10^{\mathrm{ab}} \pm 1.04 \& 3.19^{\mathrm{ab}} \pm 0.00 \mathrm{mg} / \mathrm{dl}$ respectively . In addition, itcould be 

Hyperlipidemic Rats

revealed that significant and markedly increased in total protein and albumin were recorded for rats fed on hypercholesterolemic diet supplemented with grape seeds powder $(5 \% \& 10 \%)$ and nanoparticles of grape seeds $(2 \% \& 4 \%)$ when compared with the positive control . Except rats fed on hypercholesterolemic diet supplemented with NGS2\% had markedly decreased in total protein.The results agreement with El-Denshary, E.S., et al. (2015)who concluded that both chitosan nanoparticles (CNPs) and quercetin (Q) could induce protection against hepatotoxicity. Consequently, CNPs was a promisecandidate as drug delivery in liver diseases treatments.

Table (10). Effect of Nanoparticles of grape seeds and its powder on Urea, Uric and Creatinine in obesehyperlipidemic rats (mean $\pm S D$ ).

\begin{tabular}{|c|c|c|c|}
\hline \multirow[t]{2}{*}{ Parameters } & $\begin{array}{l}\text { Urea } \\
\mathrm{mg} / \mathrm{dl}\end{array}$ & $\begin{array}{c}\text { Uric acid } \\
\mathrm{mg} / \mathrm{dl}\end{array}$ & $\begin{array}{c}\text { Creatinine } \\
\mathrm{mg} / \mathrm{dl}\end{array}$ \\
\hline & Mean \pm SD & Mean \pm SD & Mean \pm SD \\
\hline Control negative (C-) & $20.87^{\mathbf{b}} \pm 1.26$ & $2.43^{\mathrm{c}} \pm 0.14$ & $0.88^{\text {cd }} \pm 0.08$ \\
\hline Control positive $(\mathrm{C}+)$ & $28.75^{\mathrm{a}} \pm 1.22$ & $4.77^{\mathrm{a}} \pm 0.82$ & $1.21^{\mathbf{b c}} \pm 0.05$ \\
\hline N.G.S 2\% & $21.97^{b} \pm 1.85$ & $2.70^{\mathbf{c}} \pm 0.34$ & $1.53^{b} \pm 0.55$ \\
\hline N.G.S 4\% & $23.30^{\mathbf{b}} \pm 2.80$ & $3.80^{\mathbf{b}} \pm 0.49$ & $2.25^{\mathrm{a}} \pm 0.44$ \\
\hline G.S.P. 5\% & $25.04^{\mathbf{a b}} \pm 3.09$ & $3.13^{\mathbf{c}} \pm 0.188$ & $0.62^{d} \pm 0.66$ \\
\hline G.S.P. $10 \%$ & $25.40^{\mathbf{a b}} \pm 5.50$ & $2.98^{\mathbf{c}} \pm 0.14$ & $0.91^{\text {cd }} \pm 0.18$ \\
\hline F. Value & 3.46 & 14.79 & 15.11 \\
\hline Sig. & 0.024 & 0.000 & 0.000 \\
\hline
\end{tabular}

A possible mechanism of reduced activities of the tested enzymes and hepatoprotective effect of red grape seeds extract may be related to their antioxidant effect of the phenolic compounds and flavonoids.Nada SA, et al., (2015) investigate the protective effect of grape seed extract (GSE) and/or silymarin againstthioacetamide (TAA)-induced hepatic fibrosis in Sprague-Dawley rats. It reported that administration of Grape seed extractGSE (100 and $200 \mathrm{mg} / \mathrm{kg}$ ) and/or silymarin attenuated TAAinducedhepatic fibrosis, improved enzymes and reduced the oxidative stress in dose dependant manner Histopathologicalstudy showed disruption of the hepatic architecture and collagen fibers deposition in the portal tract of TAA-injectedgroup. Concomitant treatment with GSE (100 and 200 $\mathrm{mg} / \mathrm{kg}$ ) and/or silymarin significantly improvedhistopathological structure of liver tissue in variable degrees.

\section{3-8. Kidney Functions:}

Data in table (10) showed the effect of grape seeds powder (GSP) and nanoparticles grape seeds (NGS) on serum concentrations ofUrea, Uric and Creatinine in obese hyperlipidemic rats. It could be observed that urea, uric acid and creatinine was significantly increased in rats fed on hypercholesterolemic diet without supplementation (positive control group) with a mean value $28.75^{\mathrm{a}}$ $\pm 1.22,4.77^{\mathrm{a}} \pm 0.82$ and $1.21^{\mathrm{bc}} \pm 0.05 \mathrm{mg} / \mathrm{dl}$ when compared with the negative control group with a mean value $20.87^{\mathbf{b}} \pm 1.26,2.43^{\mathrm{c}} \pm 0.14$ and $0.88^{\mathrm{cd}} \pm 0.08 \mathrm{mg} / \mathrm{dlrespectively.}$

In addition, it revealed that, significant decreased in urea were found for rats fed on hypercholesterolemic diet supplemented with NGS $2 \%$ \& $4 \%$ and non-significant decreased for rats fed on hypercholesterolemic diet supplemented with GSP 5\%\&10\%, when compared with positive control group. Moreover, it could be observed that, significant decreased was found in uric acid for rats fed on hypercholesterolemic diet supplemented with Nanoparticles of grape seeds NGS and its powder GSP by different levels compared with control positive . Also,significant decreased was found in creatinine for rats fed on hypercholesterolemic diet supplemented with GSP 5\%\&10\% compared with control positive .On the other hand, it could be observed that markedly and significant increased in creatinine were recorded for rats fed on hypercholesterolemic diet supplemented with NGS $2 \% \& 4 \%$ compared with control positive.

\section{Conclusions}

It can be concluded that nanoparticles isolated from red grape seed specially Cellulose Nanocrystals (CNC) had a significant positive effects against obesity and Hyperlipidemic than the effects of Grape Seeds Powder. Hence, the study may be repeated on patients with hyperlipidemia for possible beneficial effect on humans. 


\section{REFERENCES}

Adisakwattana, S., Jiphimai, P., Prutanopajai, P., Chanathong, B., Sapwarobol, S., and

Ariyapitipan, T. (2010): Evaluation of $\alpha$-glucosidase, $\alpha$ - amylase and protein glycation inhibitory activities of edible plants. Int. J. Food. Sci. Nutr., 61:295-305.

Ahn, H.S., Jeon, T.I., Lee J.Y., Hwang, S.G., Lim, Y., Park, D.K.(2002): Antioxidative activity of persimmon and grape seed extract: in vitro and in vivo. Nutr Res; 22:1265-73.

Albrecht, M.A., Evans, C.W., and Raston, C.L. (2006): Green chemistry and the health implications of nanoparticles. Green Chem., 8(5): 41732.

Armitage P and Berry G. (1987): Statistical method in medical research Blackwell, oxford, UK, p p, 93-213.

Chacona, M.R.,Ceperuelo-Mallafrea, V., Maymo-Masipa, E., Mateo-Sanzb, J.M., Arolac, L.,Guitierreza, C., Fernandez-Reald, J.M., Ardevolc, A., Simona, I., and Vendrella, J.(2009): Grape-seed procyanidins modulate inflammation on human differentiated adipocytes in vitro. Cytokine, 47, 137-142.

Clouatre, DL ., and Kandaswami, C. (2005):Grape seed extract. In: Coates P, Blackman M,Cragg G, et al., eds. Encyclopedia of Dietary Supplements. New York, NY: Marcel Dekker; 309-325.

El-Denshary, E.S., et al. (2015): Possible Synergistic Effect and Antioxidant Properties of Chitosan Nanoparticlesand Quercetin against Carbon Tetrachloride-Induce Hepatotoxicity in Rats. Soft Nanoscience Letters, 5, 36-51.http://dx.doi.org/10.4236/snl.2015.52005.

Formiguera, X. and Canton, A. (2004): Obesity: epidemiology and clinical aspects. Best Pract. Res. Clin. Gastroentenol ., 18:1125-1146.

God, J.M., Tate, P., and Larcom, L.L. (2007): Anticancer effects of four varieties of muscadine grape. J. Med. Food. 10, 54-59.

Goupy, P., Hugues, M.,Boivin P.,and Josephe M. A.,(1999): Antioxidant composition and activity of barley (Hordeum Vulgare) and malt extracts and of isolated phenolic compounds.J.Sci Food Agric 79:1625-1634.

GUI Yu,LU Hong-jia,ZHANG Duan-li, et al.(2014): Hypolipidemic Effects of Different Particle Sizes of Cellulose from Sweet Potato Residue in Ovariectomized Hyperlipidemia Rats[J]. Food Science, 2014, 35(5): 218-222.

G Xu, X Huang, L Qiu, J Wu and Y Hu (2007) :Mechanism study of chitosan on lipid metabolism inhyperlipidemic rats. Asia Pac J Clin Nutr 2007;16 (Suppl 1):313-317.

Jacobson, TA., Miller, M., and Schaefer, EJ. (2007):Hypertriglyceridemia and cardiovascular risk reduction. Clin. Ther ., 29: 763-777.

Kalia, B., Kaith, S. and Kaur, I. (2009): Pretreatments of natural fibers and their composites-a review,"Polymer Engineering and Science, vol. 49, no. 7, pp. 1253-1272.

Hassan, M. L., Abou-Zeid, R. E, Fadel, S. M., El-Sakhawy, M., and Khiari, R. (2014):Cellulose nanocrystals and carboxymethyl cellulose from olive stones and their use to improve paper sheets properties. International Journal of Nanoparticles 7 (3-4), 261-277.

L. E. Wise, M. Murphy, and A. A. D'Addieco, (1946): Chlorite holocellulose, its fractionation and bearing on summative wood analysis and on studies on hemicelluloses.Paper Trade Journal, vol. 122 , no. 2, pp. 35-43.

Leifert, W.R., and Abeywardena, M.Y. (2008): Grape seed and red wine polyphenol extracts inhibit cellular cholesterol uptake, cell proliferation, and 5-lipoxygenase activity. Nutr. Res., 28: 842850 .

Liu Shaohua and Li. Yunong (2016): effect of nano sweet potato residue cellulose on blood glucose level of athletes. Carpathian Journal of Food Science and Technology 2016, 8(3), 13-21

Lowry, O.H.; Rosebrough, N.J.; Farr, A.L.; Radall, R.J. (1954): Protein measurement with the Folin phenol reagent. J. Biol. Chem.193, 265-267.

M. L. Hassan, R. E. Abou-Zeid, R. Khiari, S. M. Fadel, and M. El-Sakhawy, (2014): Cellulose nanocrystals and carboxymethyl cellulose from olive stones and their use to improve paper sheets properties.International Journal of Nanoparticles, vol. 7, no. 3- 4. 
Nanoparticles Effects of Red Grape (Vitis vinifera) Seeds and Grape Seeds Powder on Obese Hyperlipidemic Rats

Mayer, R., Stecher, G., Wuerzner, R., Silva, RC ., Sultana, T. ,Trojer, L. ,Feuerstein, I. , Krieg, C., Abel, G., Popp, M., Bobleter, O., and Bonn, GK .(2008):Proanthocyanidins: Target compounds as antibacterial agents.J. Agric. Food Chem., 56: 6959-6966.

Mattila P.,Astola J., and Kumpulainen, J.,(2000):Determination of flavonoids in plant material by HPLC with diode-array and electro-array detections.J.Agric Food Chem., 48, 5834-5841.

Meyer, A.S., Yi, O.S., Pearson, D.A., Waterhouse, A.L., and Frankel, E.N., (1997): Inhibition of human low density lipoprotein oxidation in relation to composition of phenolic antioxidants in grapes (Vitis vinifera). J. Agric. Food Chem. 45, 1638-1643.

Moreno, D.A., Ilic, N., Poulev , A., Brasaemle ,D.L., Fried, S.K., and Raskin ,I. (2003): Inhibitory effects of grape seed extract on lipases. Nutrition, 19: 876-879.

Nada SA, Gowifel AMH, El-Denshary EES, Salama AA, Khalil MG, et al. (2015): Protective Effect of Grape Seed Extract and/orSilymarin Against Thioacetamide-induced Hepatic Fibrosis in Rats . J Liver 4: 178. doi:10.4172/2167-0889.1000178

Nandakumar, V., Singh, T., and Katiyar, SK. (2008): Multi-targeted prevention and therapy of cancer by proanthocyanidins. Cancer Lett ., 269: 378- 387.

Novaka, I., Janeiroa, P., and Serugab, M. (2008): Oliveira-Brett, A.M. Ultrasound extracted flavonoids from four varieties of Portuguese red grape skins determined by reverse-phase highperformance liquid chromatography with electrochemical detection.Anal. Chim. Acta , 630, $107-115$.

Pascale G. Mireille H. Patrick B. and Marie J. Amiot. (1999): Antioxidant composition and activity of barley (Hordeum Vulgare) and malt extracts and of isolated phenolic compounds.J Sci Food Agric 79; 1625-1634.

Pinent, M., Blay, M., Bladé, MC. , Salvadó, MJ., Arola, L., and Ardévol, A. (2004): Grape seedderived procyanidins have an antihyperglycemic effect in streptozotocin-induced diabetic rats and insulinomimetic activity in insulin-sensitive cell lines. Endocrinology, 145: 4985-4990.

Pirjo M. Jouni A. and Jorma K. (2000): Determination of flavonoids in plant material by HPLC with diode-array and electro-array detections .J .Agric Food Chem.48, 5834-5841.

Reeves, P., F.H. Nielsen and G .Fahmy, (1993): AIN-93 Purified Diets for Laboratory Rodents: Final Report of the American Institute of the Nutrition Ad Hoc Writing Committee on the Reformulation of AIN-76A Rodent Diet.J. Nutrition, 123:1939-151.

Shanmuganayagam, D.,Warner, T.F., Krueger, C.G.,Reed, J.D., and Folts,J.D. (2007): Concord grape juice attenuates platelet aggregation, serum cholesterol and development of atheroma in hypercholesterolemic rabbits. Atherosclerosis, 190, 135-142.

Spranger, I., Sun, B., Mateus, A.M., de Freitas, V., Ricardo-da-Silva, J.M. (2008): Chemical characterization and antioxidant activities of oligomeric and polymeric procyanidin fractions from grape seeds. Food Chem, 108:519-32.

Terra, X. ,Montagut, G., Bustos, M., Llopiz, N., Ardèvol , A., Bladé ,C., Fernández-Larrea ,J., Pujadas, G., Salvadó, J., Arola, L., and Blay, M. (2009):Grape-seed procyanidins prevent low-grade inflammation by modulating cytokine expression in rats fed a high-fat diet. J. Nutr. Biochem ., 20: 210-218.

Wada, M., Kido, H., Ohyama, K., Ichibangas, T., Kishikaw, N., Ohba, Y., Nakashima, M.N., Kurod, N., and Nakashima, K. (2007):Chemiluminescent screening of quenching effects of natural colorants against reactive oxygen species: evaluation of grape seed, monascus, gardenia and red radish extracts as multi-functional food additives. Food Chem.101, 980-986.

Wise, L.E., Murphy, M. and D'Addieco, A.A. (1946):Chlorite holocellulose, its fractionation and bearing on summative wood analysis and on studies on hemicelluloses', Paper Trade Journal, $122(2), 35-43$.

Yamakoshi, J., Kataoka, S., Koga, T., and Ariga, T. (1999):Proanthocyanidin-rich extract from grape seeds attenuates the development of aortic atherosclerosis in cholesterol-fed rabbits. Atherosclerosis, 142: 139-149.

Zhong Q Wang; Yongmei Yu; Xian H Zhang; Z Elizabeth Floyd; Anik Boudreau; Kun Lian and William T Cefalu (2012):Comparing the effects of nano-sized sugarcane fiber with cellulose and psyllium on hepatic cellular signaling in mice. International Journal of Nanomedicine 2012:7 2999-3012. 